\title{
Determinants of rice by-products utilization as feed and their management in Ethiopia: the case of Fogera District
}

\author{
BIMREW ASMARE ${ }^{1, \vartheta}$, ZEMENU YAYEH $^{2}$ \\ ${ }^{1}$ Department of Animal Production and Technology, College of Agriculture and Environmental Sciences, Bahir Dar University, P.O.Box 5501, Bahir \\ Dar, Ethiopia. "email: limasm2009@gmail.com \\ ${ }^{2}$ Department of Animal Sciences, College of Agriculture and Natural Resources, Debre Markos Uni versity, Debre Markos, Ethiopia
}

Manuscript received: 19 March 2018. Revision accepted: 2 May 2018.

\begin{abstract}
Asmare B, Yayeh Z. 2018. Determinants of rice by-products utilization as feed and their management in Ethiopia: the case of Fogera District. Asian J Agric 2: 1-7. This study was conducted with the objective to determine the status of farmers' rice by-product utilization as feed-in Fogera district, northwestern Ethiopia. Eighty smallholder farmers were selected based on livestock population and rice production access. A semi-structured questionnaire was administered to selected farmers systematically. The collected data was analyzed using SPSS descriptive statistical analysis. The results indicated that most respondents in the study area were within the age range of 31 to 50 years (55\%). Education status of respondents showed that most household heads were able to read and write (27.5\%), followed by elementary school $(26.25 \%)$, and high school (17.5\%) completed. The main dry season feed in most households (46.25\%) was found to be grazing and crop residues. The majority (64.62\%) of farmers used rice by-products as livestock feed, followed by both feed and house construction. Types of by-products used for animal feed by respondents elucidated majority (61.5\%) used rice straw, with a proportion $(26.15 \%)$ rice bran and $(12.30 \%)$ used both straw and bran for animal feed based on availability. The sources of rice by-products indicated for many of respondents $(66.7 \%)$ was farm produced, $18.5 \%$ use purchased and $18.4 \%$ get rice by-products both from farm produced and purchasing for their animal feed. Type of animals fed rice by-products included cattle in the case of majority of respondents (49.23\%), cattle and equine followed (24.62\%), and all animals (13.85\%), respectively. In livestock owners, rice byproducts are fed to livestock as sole feed and mixed with other feeds, however, the majority (69.2\%) of households provide sole followed by both sole and mixed with other feeds (16.9\%). Many of the respondents (55\%) apply drying followed by addition of saltwater $(22.5 \%)$ as method of improving the rice by-products. The main constraints observed in rice by-products utilization as feed were seasonal deficiency of by-products $(25.5 \%)$ followed by lack of awareness $(16.25 \%)$. Though these problems prevailed in the study area, rice by-products are being used as a major crop residue feed with little or no improvement applied. Generally, it can be included that rice by-products were found very important feed resources in the rice-dominated farming system of Fogera district. To exploit these products properly, farmers need to be assisted through proper agricultural extension service and supply in the form of credit service. Moreover, further detailed on-farm experimentation should be done to demonstrate better utilization of the products as livestock feed.
\end{abstract}

Keywords: Crop-livestock, feed, rice by-products, rice straw, rice bran

\section{INTRODUCTION}

The economy of Ethiopia is largely dependent on agriculture which contributes about $43.2 \%$ of the country's Gross Domestic Product (GDP), and about $85 \%$ of the population is engaged in it (CSA 2016). In the country, crops are grown for one or more main products such as food grain and by-products. The by-products such as straws and stubble grazing are leftovers after harvesting, and after processing are 'by-products' of the main crop (Adri Vink 2015). Feed shortage, both in terms of quantity and quality, is a major problem hindering the development of livestock industry in Ethiopia (Ahmed et al. 2010; Solomon et al. 2010). The common feed resources available in the high and mid-lands of Ethiopia are mainly natural pasture, crop residues and stubbles (Mesay et al. 2013; Zewdie and Yoseph 2014), and natural grazing land is the predominant feed source in lowlands (Malede and Takele 2014). In the integrated crop-livestock production systems, crop residues are the main feed resources. Fallow lands, forest, and shrublands are also the feed resources in different agro- ecologies of Ethiopia (Ahmed et al. 2010). The factors contributing to this deficit in dry matter (DM) supply are fast deterioration of the natural grazing land associated with a rise in crop cultivation, overstocking, and recurrent droughts.

In Ethiopia, the tendency of allocating natural grazing lands for crop cultivation has been increased to satisfy the grain production needs of rapidly increasing human population. One alternative feed resource is crop residue, especially cereal residue. Residues of cereals and pulses account for about $26 \%$ of the total feed utilized and ranked second to grazing $(64 \%)$ in mixed crop-livestock production system of Ethiopia (CSA 2016). With an increase in human population, more land is used to crop production, and only fragments of marginal lands will be left for forage production in Ethiopia. Consequently, ruminants feed largely on crop residues particularly on cereal straws as their basal diet (Fekede et al. 2011; Dawit et al. 2013). 
Table 1. Rice Production, No of HHs and area coverage (20092015) in Fogera District, Ethiopia.

\begin{tabular}{cccccc}
\hline $\begin{array}{c}\text { Production } \\
\text { year }\end{array}$ & $\begin{array}{c}\text { Land } \\
\text { coverage }\end{array}$ & $\begin{array}{c}\text { No of kebele } \\
\text { producing }\end{array}$ & \multicolumn{3}{c}{$\begin{array}{c}\text { No of households } \\
\text { Male }\end{array}$} \\
\hline $2009 / 10$ & 9256 & 23 & 11026 & 1111 & 12137 \\
$2010 / 11$ & 11146 & 26 & 12354 & 1725 & 14079 \\
$2011 / 12$ & 15119 & 26 & 17094 & 1325 & 18419 \\
$2012 / 13$ & 16070 & 27 & 20240 & 1325 & 21565 \\
$2013 / 14$ & 19310 & - & - & - & - \\
$2014 / 15$ & 19334 & - & - & - & - \\
$2015 / 16$ & 20896 & - & - & - & - \\
\hline
\end{tabular}

Source: Fogera District Office of Agriculture (2017)

Cereal crops, like rice, are being expanded in Ethiopia which helps in alleviating livestock feed shortage. Rice has become a highly strategic and priority commodity for food security in Africa (Table 1). The discovery of wild rice in the Fogera plain in the early 1970s, was the basis for rice introduction in Fogera district as well as in the Amhara region. Since then, Fogera district is regarded as one of major rice production areas of Ethiopia. In Fogera, potentially about 35,300 smallholders are engaged in rice production with average land size of 0.58 ha per household with a potential production of 85,990 tons of rice. The existing land coverage for rice production is above 20,000 hectares and rice is known as "white gold".

The land size for rice cultivation has increased and there is a tendency to change the style of production from other crops to rice by most of the farmers settling on
Fogera plains. The primary importance of any crop residue management system is to maximize the economic benefit from the waste resource and maintain acceptable environmental standards. Hence, proper use of crop residues including rice by-products could help to mitigate the problem of livestock feed in the highlands of Ethiopia. However, no organized study conducted on the farmers' perception about the utilization has been done in the area. Specifically, farmers awareness about the use of such byproducts traditionally and there is little or no knowledge on the status of utilization and the prevailing constraints in the study area. Therefore, this assessment was done to determine the status of rice by-product utilization and to identify constraints available in the study area.

\section{MATERIALS AND METHODS}

\section{Description of study area}

Fogera district is one of the districts of Amhara National Regional State and is found in South Gondar Zone, Ethiopia. It is situated at $11058 \mathrm{~N}$ latitude and 370 $41 \mathrm{E}$ longitude. The district is bordered by LiboKemkem district in the north, Dera district in the south, Lake Tana in the west and Farta district in the east. The altitude ranges from 1774 up to 2410 masl allowing a favorable opportunity for wider crop production and better livestock rearing (IPMS 2005).

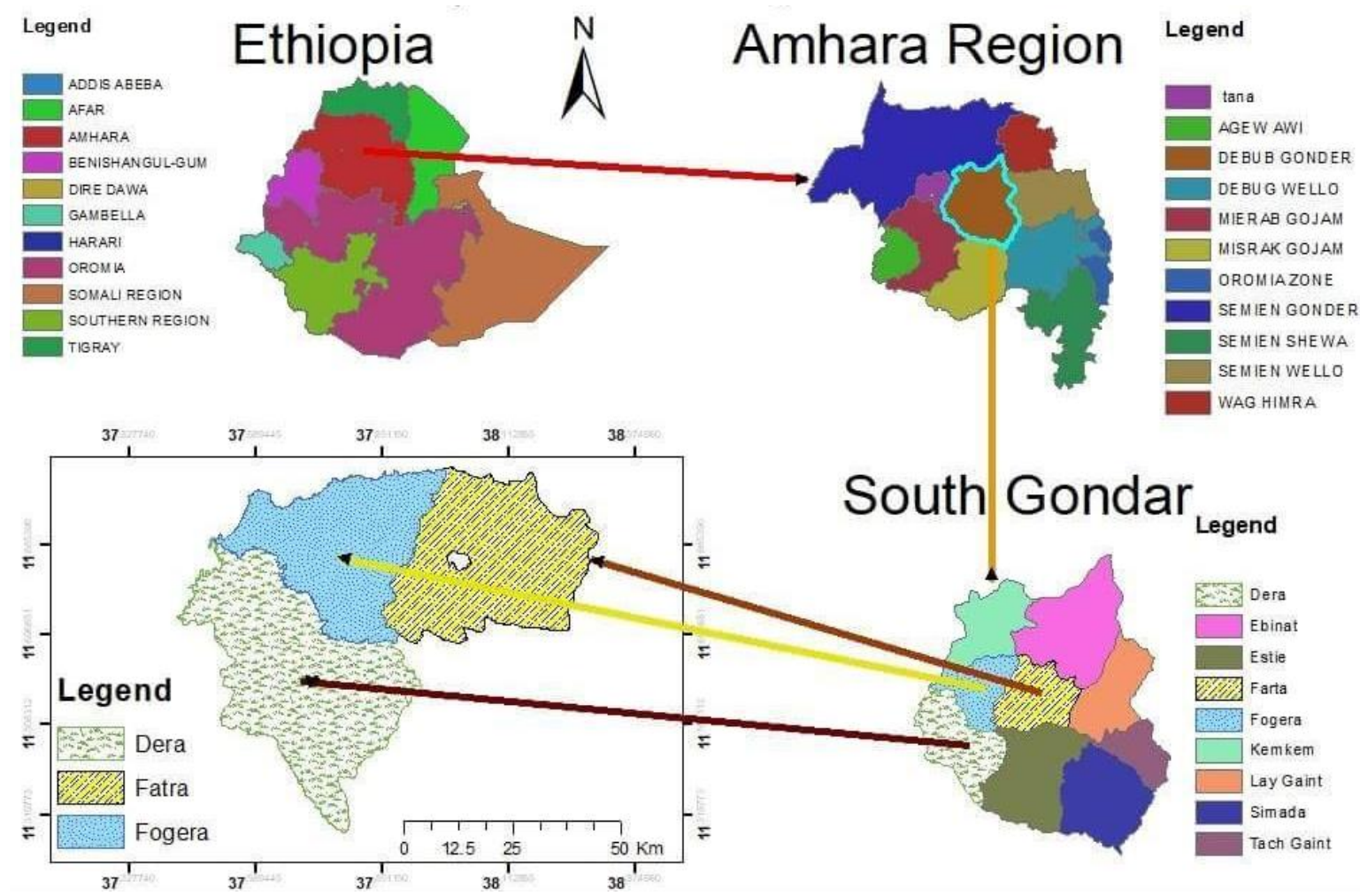

Figure 1. Map of study area in Fogera District, Amhara National Regional State, South Gondar Zone, Ethiopia. 


\section{Sampling design}

From the district, two rice producing Kebele's (local administration) were purposely selected to represent the study population. A cross-sectional and retrospective type of studies were conducted using survey questionnaires, group discussion and observation were used to collect data on characteristics and practices of rice by-product utilization in smallholder farming systems.

\section{Data collection and statistical analysis}

The primary data was collected through a crosssectional investigation. Semi-structured questionnaire was used to include data pertaining to socio-economic characteristics: demographic nature, size of household education and age. Farm size, livestock species kept, methods and strategies of rice by-products utilization were collected. Livestock holding per household was converted to tropical livestock unit using the conversion factors (ILCA 1992). Constraints related to feed shortage in terms of quantity and quality visa vis mitigation strategies were collected. The data was complemented with information obtained from key informants and secondary data derived from district office of agriculture. The collected data was systematical coded and analyzed with Statistical Package for Social Sciences (SPSS) (version 20 2011).

\section{RESULTS AND DISCUSSION}

\section{Gender, age, and educational characteristics of respondents}

The age and educational characteristics of respondents are shown in Table 2. Of the total of respondents, the majority (94\%) were male while the rest of them were female. This may be associated with the fact that maleheaded households have more access to agricultural technologies due to their exposure to different out-of-house issues. The findings agreed with different reports (Mekuriaw et al. 2011; Assefa et al. 2014; Asmare and Yayeh 2017). Most respondents in the study area were in the range of 31 to 50 years $(55 \%)$. The results of the current findings disagree with reports of Asmare et al. (2016) and Atalayeetal. (2014) who reported the average age of respondents was $43.2 \pm 1.0$ years for Metkele Zone and Burie District, Ethiopia, respectively.

The mean family size of respondents in the study area was 6.55 per household. The average family size in the study areas was comparable but relatively higher to 6.22 (Kebede et al. 2012) reported for Bure district of ANRS, and it is also higher than the two lowland districts (Mandura and Pawe) of Metekel zone of BenshangulGumz region ranging 6.04 to 6.94 (Mekuriawet al. 2011). The result was also larger than that reported by Tesfaye (2007) with overall mean family size of 5.7 persons in Metema district in Northwest Ethiopia and national rural average (5.1) (ERSS 2013).

Many household heads were able to read and write $(35.38 \%)$ with comparable proportion of elementary school completed households $(33.85 \%)$. The result also showed that there were still many $(27.69 \%)$ that could not read and write in the area. This indicates there is still the highest numbers of respondents who could not read and write in all altitudes which could have high influences on awareness and adoption of emerging technologies and extension activities. This agreed with Ezeibeet al. (2014) who reported that the low levels of education of the households influence adoption of improved poultry management practices. Furthermore, Bruna et al. (2014) reported that education is the main issue in agricultural development (especially primary and secondary schooling had higher impact on agricultural development compared to any other level of education). Therefore, in the study area, these $(36.38 \%)$ illiterate had their own impact on utilization of existing resources, technology transformation, and adoption in the study areas.

\section{Land and livestock holding of respondents}

The land and livestock holding characteristics of respondent are shown in Table 3. Mixed crop-livestock production system is the dominant farming system in the district. The livelihood of respondents in the study area was solely (100\%) crop-livestock farming. Livestock production is subsistence-oriented and is an important component of the mixed farming system and is well integrated with crop production. Livestock species kept by the farmers are typically cattle, sheep, goats, equines, and chickens. Cattle are the dominant species per household, mainly used for draught power, followed by milk and meat production, income, and manure for maintaining soil fertility. The results agree with reports of different authors (Selamawit 2015; Asmare et al. 2016; Zeru and Lijalem 2016) in Ethiopia.

The average landholding per household in the study area was 1ha from which on average 0.9 ha was used for crop production and the rest (0.1ha) used for forage production purposes. The major crops grown in the study area were rice, maize, finger millet, teff, hot pepper and niger seed which cover 38.13, 24.12, 22.56, 6.61, 4.66 and $2.33 \%$, respectively. The overall land covered by the above crops occupies about $98.14 \%$ of the total cultivable land while the rest $(1.86 \%)$ was covered by horticultural crops like potato and lettuce. In the district from the total cultivable land, $43.58 \%$ was cultivated using irrigation and residual moisture from the rainy season. This indicates that the district has much irrigable land for food and forage crop production.

\section{Livestock feed resources}

The dry and wet season livestock feeds resources of respondents are shown in Table 4. The type of available feed resources in the study area includes natural pasture, crop residue, hay and supplements like salt, and some indigenous and improved fodder trees. The feed resources of livestock in dry and wet seasons were found almost the same which might be due to shortage of land that has made respondents not base only on grazing and use straw and other feeds in both seasons. Similar reports were also reported for different areas of Ethiopia (Mekuriaw and Asmare 2014; Asmare et al. 2016; Zeru and Lijalem 2016). 
Table 2. Age and educational characteristics of respondents.

\begin{tabular}{ll}
\hline Characteristics of respondents & Frequency (Percent) \\
\hline Age category & $17(21.25 \%)$ \\
18-30 years & $22(27.5 \%)$ \\
$31-40$ years & $22(27.5 \%)$ \\
41-50 years & $12(15 \%)$ \\
$51-60$ years & $7(8.75 \%)$ \\
$>$ 60 years & $80(100 \%)$ \\
Total & \\
& \\
Educational characteristics & $14(17.5 \%)$ \\
Illiterate & $22(27.5 \%)$ \\
Read and Write & $21(26.25 \%)$ \\
Elementary school & $14(17.5 \%)$ \\
High School & $10(12.5 \%)$ \\
Certificate and above & $80(100 \%)$ \\
Total &
\end{tabular}

Table 3. Land and livestock holding characteristics of respondents.

\begin{tabular}{lc}
\hline Species of livestock & Holding (TLU) \\
\hline Cattle (TLU) & 4.71 \\
Sheep (TLU) & 0.2 \\
Goats (TLU) & 0.21 \\
Donkey (TLU) & 0.8 \\
Mule (TLU) & 0.8 \\
Chicken (N) & 11 \\
Honeybee colony (N) & 4 \\
Landholding (ha) & 1 \\
Cropland (ha) & 0.9 \\
Forage land (ha) & 0.1 \\
\hline Note: N (number), ha (hectare), TLU (Tropical Livestock
\end{tabular}

Note: N (number), ha (hectare), TLU (Tropical Livestock Unit)

Table 4. Dry and wet seasons of livestock.

\begin{tabular}{lcc}
\hline Dry season feed & N & Percent \\
\hline Grazing and crop residues & 42 & 52.5 \\
Grazing, crop residues and hay & 21 & 26.25 \\
Grazing, crop residues, and improved fodder & 17 & 21.25 \\
& & \\
Wet season feed & & \\
Grazing and crop residues & 43 & 53.75 \\
Grazing, crop residues, and hay & 15 & 18.75 \\
Grazing, crop residues, hay, and improved fodder & 12 & 15 \\
Grazing, crop residues, and concentrate & 10 & 12.5 \\
Total & 80 & 100 \\
\hline Note: N (number) & \multicolumn{3}{l}{}
\end{tabular}

Seasonal livestock feed shortage was the major problem for livestock production in both study areas, in which farmers have different strategies to mitigate the problems. The livestock feed resources and feeding system of the current study area agrees with different reports in different parts of the country (Tonamo et al. 2015: Asmare et al. 2016; Gashe et al. 2017). As indicated in other parts of the country (Fetsumet al. 2009), growth crop production and increment of livestock number are considering adding the feed shortage in the study areas.

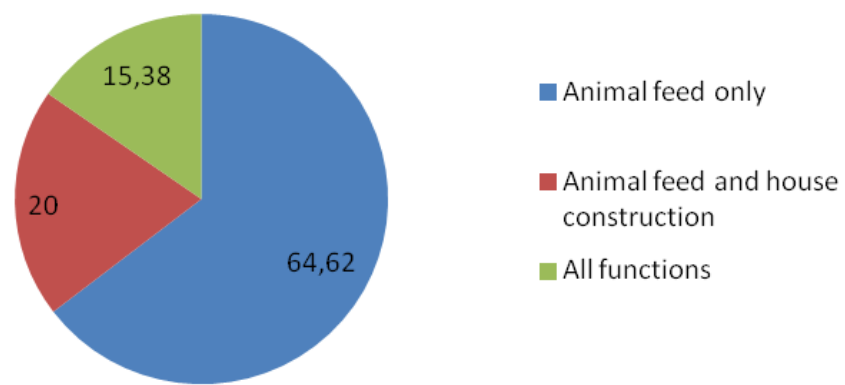

Figure 2. Function of rice by-products for the household.

\section{Rice by-product utilization of households}

The Function of rice by-products for the household is shown in Fig 2. Result of overall rice by-product utilization indicated that rice by-products are used for different functions such as animal feed and assist in house construction as well as local mattress making. From the total of respondents, the majority $(64.62 \%)$ households in the study area use rice by-products as animal feed, followed by both feed and house construction. The current finding agrees with various reports (Atuhaire et al. 2014; Valbuena et al. 2015; CSA 2016).

\section{Utilization of rice by-products as feed for livestock}

The species of livestock animals fed rice by-products in the study area are shown in Table 5. Most respondents 43 $(66.7 \%)$ use farm products, $12(18.5 \%)$ use purchased and $10(18.4 \%)$ get rice by-products both from farm produced and purchasing for their animal feed. Similar trend of utilization has been reported in research conducted for crop residue trade-off by Valbuena et al. (2015). In the study area, rice by-products in the study area are used as feed for different livestock species including equine. Overall, the majority $(49.23 \%)$ of respondents feed their livestock rice by-products for cattle and equine, followed by cattle $(24.62 \%)$, and all animals (13.85\%). In Ethiopia, different authors reported that the rice straw and bran could be used as animal feed for different species (Derso 2009; Asmare et al.2010; Hailu et al. 2011). Moreover, the information was in line with Heuze and Tran (2015) showed that rice and its by-products could be used for different species of animals.

Table 5. Species of animals fed rice by-products and feeding methods of respondents.

\begin{tabular}{lcc}
\hline Type of animals feed RB & N & Percent \\
\hline Cattle & 18 & 22.5 \\
Equine & 14 & 17.5 \\
Cattle and equine & 32 & 40 \\
Cattle and sheep & 7 & 8.75 \\
All animals & 9 & 11.25 \\
Total & 80 & 100 \\
& & \\
Sole & 45 & 69.2 \\
mixed with other feeds & 16 & 13.9 \\
Both methods & 19 & 16.9 \\
Total & 80 & 100 \\
\hline
\end{tabular}


In the current study area, rice by-products were fed to livestock as sole feed and mixed with other feeds. However, the majority $(69.2 \%)$ of households provide sole either straw or bran followed by both sole and mixed with other feeds $(16.9 \%)$. The finding showed that rice straw and rice bran are being used as sole feed or mixed with other supplementary feeds. In all respondents, the amount of rice straw and bran offered to animals in the study area is done based on estimation without quantification for each animal. The finding agreed with earlier reports in Ethiopia (Tesfaye and Chairatanayuth 2007).

\section{Nutritional improvement of rice by-products}

The current practices of rice by-product nutritional improvement strategies of respondents are shown in Table 6. The study revealed that respondents use different methods to improve rice by-products, particularly rice straw such as drying, saltwater spraying before feeding, urea treatment, and chopping of straw. However, many respondents, $54(83.33 \%)$, apply drying and chopping followed by drying only (15\%). Although these physical treatments are important in increasing the intake of rice byproducts particularly rice straw, the practices have no effect on nutritional improvement of feeds (McDonald et al. 2010). Smallholder farmers do not apply better nutritional improvements on rice by-products such as urea treatment due which might be associated with lack of inputs and awareness. However, as rice by-products are usually low in crude protein, it is vital that supplementation with a protein source and a more easily accessible energy source will improve the performance and production of the animals (Sarnklong et al. 2010; Alam et al. 2016).

\section{Skill of respondents on rice by-product management}

Among rice producers respondents only $23 \%$ have got training on rice by-product utilization techniques while the majority $(77 \%)$ have not got any training. The status of training of respondents in the current study is comparable to the results of Asmare et al. (2016) for desho grass utilization in Buriezuria district in northwestern Ethiopia. However, the importance of training and visit to farmers' fields has significant importance on the adoption of technology in tropics (Hussan et al. 1994; Rahman 2007). In line with this, (Ampaire and Rothschild 2010) indicated that farmers who had received more training and support had less disease in pigs in the six months preceding the study than those who had not been trained or who had the animals for a shorter period.

\section{Suggested rice by-product improvement strategies}

The rice by-product improvement strategies of respondents are shown in Table 7. Respondents were asked to suggest future rice by-products improvement strategies and mentioned different types. Nevertheless, many respondents were indicated that proper drying, chopping, addition of saltwater and supplementation with concentrate mixture and bran as options for improvement in the future utilization of rice by-products. This finding indicates that many extension demonstration works should be done in the area about the utilization and feed value improvement options in the study area.
It is known that the chemical treatment of roughages, like rice straw and other by-products, would increase the nutritive value of the roughage. Research conducted using lactating crossbred cows in Ethiopia, urea treated barley or teff straw were noted to replace native hay, and ammoniation was found to be economically feasible producing in milk production of cows (Derso 2009; Hailu et al. 2011). However, none of respondents suggested chemical treatment as an option of rice straw which might be associated with lack of awareness and cost implications of urea and labor. Moreover, other researchers also indicated that rice, although major feed for ruminant animals, has a low crude protein content (Khandaker et al. 2012; Su et al. 2012) indicating that it needs chemical treatments like urea treatment (McDonald et al. 2010; Nguyen et al. 2012) as well as physical treatments like chopping. Overall, treatment of straws with urea might be most suitable method for small-scale farmers to improve the quality of straws (Hanafi et al. 2012). On the other hand, urea price is increasing, and impacts on the high cost of roughage unless there are chemicals or options are sought.

\section{Constraints of rice by-product utilization as feed}

The major constraints of rice by-product utilization as feed by respondents is indicated in Table 8 .

Table 6. Rice by-products improvement strategies of respondents.

\begin{tabular}{lcc}
\hline Method & N & Percent \\
\hline Drying only & 12 & 15 \\
Spray salt solution before feeding & 5 & 6.25 \\
Urea treatment & 9 & 11.25 \\
Drying and chopping & 54 & 67.5 \\
Total & 80 & $100 \%$ \\
\hline
\end{tabular}

Note: $\mathbf{N}$ (number)

Table 7. Techniques used to keep quality of rice straw by respondents.

\begin{tabular}{lcc}
\hline Techniques & N & Percent \\
\hline Proper drying & 44 & 55 \\
Addition of saltwater on straw & 18 & 22.5 \\
Urea treatment of straw & 8 & 10 \\
Mixing salt with bran & 6 & 7.5 \\
Supplementation & 4 & 5 \\
& 80 & 100 \\
\hline
\end{tabular}

Note: N (number)

Table 8. Constraints of rice by-product utilization by respondents.

\begin{tabular}{lcc}
\hline Constraints & N & $\%$ \\
\hline Seasonal deficiency of by-products & 18 & 22.5 \\
shortage of labor & 8 & 10 \\
Lack of inputs (e.g., chemicals) & 13 & 16.25 \\
Shortage of by-products & 10 & 12.5 \\
Lack of skill and awareness on utilization & 20 & 25 \\
Total & 80 & 100 \\
\hline
\end{tabular}

Note: $\mathrm{N}$ (number) 
The major constraints of rice by-product utilization as animal feed in the study area can be categorized as lack of awareness about feed value of rice by-products, shortage of rice products, poor processing and storage method of rice bran and lack of access to the by-product. From the listed problems, lack of awareness about the feed value of the products was found in a relatively large number of respondents $(25 \%)$, seasonal deficiency of products $(22.5 \%)$ followed by shortage of inputs $(16.25 \%)$ were the major constraints. This elucidates that there must be an intervention such as creation of awareness about the feed value of rice by-products and making accessible the products to users. The use of rice by-products in the study area was limited by lack of access and awareness in the study area. The result agrees with reports stated about crop residues in other parts of the world (de Leeuw 1997; Erenstein et al.2011; Valbuena et al. 2012).

\section{Conclusion and recommendation}

Rice by-products such as straw and bran were used for different purposes including animal feed in the study area. The rice by-product utilization indicated that most respondents in the study area use rice by-products as animal feed, followed by both feed and house construction. The sources of rice by-products for animal feed were both farms produced and purchased. All herbivore animals were fed rice by-products as sole or basal diet and supplementary to other feed types. Simple drying and chopping were used as a treatment for rice straw before being fed to animals; however, rice bran was not treated. Although rice by-products are livestock feeds in the study area, smallholder farmers were not able to use such products effectively due to lack of awareness and shortage of resources. Hence, awareness creation should be given to smallholder farmers on the utilization of rice by-products and feed value improvement methods. Moreover, detailed experiments on physical and chemical treatment and animal evaluation of rice by-products should be conducted in the study area.

\section{ACKNOWLEDGEMENTS}

The authors would like to acknowledge all smallholder farmers who participated in the interview process.

\section{REFERENCES}

Adri V. 2015. Crop residues for animal feed especially in stall-feeding. Agromisa Foundation and CTA. Proud Press, Barneveld, Netherlands.

Ahmed H, Abule E, Mohammed K, Tryst AC. 2010. Livestock feed resources utilization and management as influenced by altitude in the Central Highlands of Ethiopia. Livestock Res Rural Dev 22 (12): 1-22

Alam, MK, Ogata Y, Sato Y, Sano H. 2016. Effects of rice straw supplemented with urea and molasses on intermediary metabolism of plasma glucose and leucine in sheep. Asian-Australasian J Anim Sci 29 (4): 523-529.

Altaye SZ, Kassa B, Agza B, Alemu F, Muleta G. 2014. Smallholder cattle production systems in Metekel zone, northwest Ethiopia. Res J Agric Environ Manag 3 (2): 151-157.

Ampaire A, Rothschild MF. 2010: Effects of training and facilitation of farmers in Uganda on livestock development. Livestock Research for
Rural Development. Volume 22, Article \#130. Retrieved October 10, 2017, from http: //www.lrrd.org/lrrd22/7/ampa22130.htm.

Asmare B, Demeke S, Tolemariam T, Tegegne F, Wamatu J, Rischkowsky B. 2016. Determinants of the utilization of desho grass (Pennisetum pedicellatum) by farmers in Ethiopia.Trop GrasslandsForrajes Tropicales 4 (2): 112-121.

Asmare B, Melaku S, Peters KJ. 2010. Supplementation of Farta sheep fed hay with graded levels of concentrate mix consisting of noug seed meal and rice bran. Trop Anim Health Prod 42: 1345-1352.

Atuhaire A, Mwebaze M, Swidiq, Okello Samuel, Lapenga KO, Kab F, Kabirizi JM. 2014. Prioritization of crop residues for improving productivity on smallholder dairy farming households in the Lake Victoria Crescent, Uganda. Open J Anim Sci 4: 103-111.

Ayalew T, Duguma B, Tolemariam T. 2013. Smallholder Cattle Production Systems in Three Districts of Ilu Aba Bora Zone of Oromia Regional State, Southwestern Ethiopia. Amer-Eur J Sci Res 8 (1): 38-46.

Ayele S, Assegid W, Jabbar MA, Ahmed MM, Belachew H.2003. Livestock marketing in Ethiopia: Performance and Development Initiatives. Socioeconomic and Policy Research Working Paper 52. International Livestock Research Institute, Nairobi, Kenya.

Bruna, NR, Barros CP, Dos JM. 2014. Education and agricultural production in Mozambique: The case of Maize. [Dissertation]. Instituto Superior de Economia e Gestão, Universidade de Lisboa, Lisboa.

CSA [Central Statistical Authority]. 2016. Agricultural sample survey livestock and livestock characteristics (private peasant holdings). Central Statistical Authority, Ethiopia.

Dawit A, Ajebu N, Banerjee S, 2013. Assessment of feed resource availability and livestock production constraints in selected Kebeles of Adami Tullu Jiddo Kombolcha District. African J Agric Res 8 (29): 4067-40731.

De Leeuw PN. 1997. Crop residues in tropical Africa: Trends in supply, demand, and use. In: Renard C (ed.). Crop Residues in Sustainable Mixed Crop/Livestock Farming Systems. CAB International, ICRISAT, ILRI, Wallingford, UK.

Eba B, Hailesilassie A, Animut G. 2015. Variability of feed sources availability and their managements in mixed crop-livestock system: The case of three watersheds in the highlands of blue Nile Basin, Ethiopia. Global J Anim Sci Livestock Prod Anim Breed. 3 (7): 235242.

ERSS [Ethiopia Rural Socioeconomic Survey]. 2013. Survey Report. Central Statistical Agency \& the World Bank, Addis Ababa, Ethiopia.

Ezeibe AB, Okorji EC, Chah JM, Abudei RN. 2014. Impact of entrepreneurship training on rural poultry farmers' adoption of improved management practices in Enugu State. African J Agric Res 9 (20): 1604-1609.

Fekede F, Agajie T, Angaw M. 2011. Producing and using alternative feeds to crop residues efficient use of crop residues: Animal Feed Vs. Conservation Agriculture Research Project. Ethiopian Institute of Agricultural Research (EIAR). Addis Ababa, Ethiopia.

Fetsum S, Solomon Z, Mikias D, Yigremachew S, Demeke M, GizachewW, and Yeshi C. 2009. Gender-Based Participatory Rural Appraisal of Farming Systems in Wombera, Bullen, and GubaWoredas. In: Gender Differentials for Planning Agricultural Research. Proc. of the Workshop on Gender Analysis in Agricultural Research. Addis Ababa, Ethiopia.

Fogera District Office of Agriculture. 2017. Fogera District in Figures. Fogera, Ethiopia.

Gashe A, Zewdu T, Kassa A. 2017. Feed Resources Gozamen District, East Gojjam Zone, Amhara Region. J Environ Anal Toxicol 7: 437. DOI: $10.4172 / 2161-0525.1000437$.

Hailu A, Melaku S, Tamir B, Tassew A. 2011. Body weight and carcass characteristics of Washera sheep fed urea-treated rice straw supplemented with graded levels of concentrate mix. Livestock Research for Rural Development.Volume 23, Article \#164. Retrieved May 8, 2017, from http: //www.lrrd.org/lrrd23/8/hail23164.htm.

Hanafi EM, ElKhadrawy HH, Ahmed WM, Zaabal MM. 2012. Some observation on rice straw with emphasis on updates of its management. World Appl Sci J 16: 354-361.

Heuzé V, Tran G, 2015. Rice Bran and other Rice By-Products. Feedipedia, a programme by INRA, CIRAD, AFZ, and FAO. http: //www.feedipedia.org/node/750 [October 5, 2015].

ILCA. 1992. International Livestock Center for Africa, Annual Program Report 1991. ILCA, Addis Ababa, Ethiopia. 
Kebede A., Tegegne F, Mekuriaw Z, Tegegne A. 2012. Characterization of Milk Production Systems in Bure District, Ethiopia. IUP J Life Sci 5 (2): 40-53.

Khandaker ZH, Uddin MM, Sultana MN, Peters KJ. 2012. Effect of supplementation of mustard oil cake on intake, digestibility, and microbial protein synthesis of cattle in a straw-based diet in Bangladesh. Trop Anim Health Prod. 44: 791-800.

Malede B, Takele A., 2014. Livestock feed resources assessment, constraints, and improvement strategies in Ethiopia. Middle-East J Sci Res 21 (4): 616-622.

McDonald AA, Edwards RA, Greenhalgh JFD, Morgan CA. 2010. Animal Nutrition. 6th ed. Pearson Education, Harlow.

Mekuriaw Y, Urge M, Animut G. 2011. Role of indigenous Bamboo species (Yushaniaalpina and Oxytenantheraabyssinica) as ruminant feed in northwestern Ethiopia. Livestock Research for Rural Development. Volume 23, Article \#185.Retrieved May 8, 2017, from http: //www.lrrd.org/lrrd23/9/meku23185.htm.

Mesay Y, Bedada B, Teklemedihin T. 2013. Enhancing the productivity of livestock production in highland of Ethiopia: Implication for improved on-farm feeding strategies and utilization. Intl J Livestock Prod 1 (1): 015-029.

Nguyen VN, Wanapat M, Khejornsart P, Kongmun P. 2012. Nutrien digestibility and ruminal fermentation characteristic in swamp buffaloes fed on chemically treated rice straw and urea. Trop Anim Health Prod 44: 629-636.

Rahman S. 2007. Adoption of improved technologies by the pig farmer of Aizawl district of Mizoram, India. Livestock Research for Rural Development. Volume 19, Article \#5. Retrieved October 10, 2017, from http: //www.lrrd.org/lrrd19/1/rahm19005.htm

Sarnklong C, Cone JW, Pellikaan W, Hendriks WH, 2010. Utilization of rice straw and different treatments to improve its feed value for ruminants: A review. Asian Australasian J Anim Sci 23: 680-692.

Seck, PA, ToureAA, Coulibaly JY, Diagne A, Wopereis, M. C. S. 2013. Impact of rice research on income, poverty, and food security in Africa: an ex-ante analysis. In: Wopereis MCS, Johnson DE, Ahmadi
N, Tollens E, Jalloh A. (eds.). Realizing Africa's Rice Promise. CABInternational, Wallingford, UK

Solomon G, Tegegne A, Gebremedhin BDirk H. 2010. Sheep and goat production and marketing systems in Ethiopia: Characteristics and strategies for improvement. IPMS (Improving Productivity and Market Success) of Ethiopian Farmers Project Working Paper 23. International Livestock Research Institute, Nairobi, Kenya.

SPSS. 2006. Statistical Package for the Social Sciences (SPSS), version 15. Chicago, USA.

Su Y, Zhao G, Wei Z, Yan C, Liu S, 2012. Mutation of cellulose synthase gene improves the nutritive value of rice straw. Asian-Aust J Anim Sci 25: 800-805.

Tesfaye A, Chairatanayuth P. 2007. Management and feeding systems of crop residues: the experience of East Shoa Zone, Ethiopia. Livestock Research for Rural Development. Volume 19, Article \#31. Retrieved May 8, 2017, from http: //www.lrrd.org/lrrd19/3/tesf19031.htm.

Tesfaye M. 2007. Characterization of cattle milk and meat production, processing, and marketing system in Metema district, Ethiopia, [Thesis]. Hawassa Univ., Awassa, Ethiopia.

Tonamo A. Tamir B. Goshu G, Belete E. 2015. Characterization of cattle husbandry practices in EsseraWoreda, Dawuro Zone, Southern Ethiopia. African J Agric Res 10 (34): 3421-3435.

Valbuena D, Homann-KeeTui S, Erenstein O, Teufel N, Duncan A, Abdoulaye T, Swain B, Mekonnen K, Germaine I, Gérard B,2015. Identifying determinants, pressures and trade-offs of crop residue use in mixed smallholder farms in Sub-Saharan Africa and South Asia. Agric Syst 134: 107-118.

Zereu G, Lijalem T. 2016. Status of improved forage production, utilization, and constraints for adoption in Wolaita Zone, Southern Ethiopia. Livestock Research for Rural Development. Volume 28, Article \#78. Retrieved May 8, 2017, from http: //www.lrrd.org/lrrd28/5/zere28078.htm.

Zewdie W, Yoseph M. 2014. Feed resources availability and livestock production in the Central Rift Valley of Ethiopia. Intl J Livestock Production. DOI: 10.5897/IJLP2013.0158. 